\title{
On-farm Validation of Bread Wheat Innovations for Supporting Extension Package Formulation in Ethiopia
}

\author{
Aklilu Nigussie $^{1}$, Wasihun Legesse ${ }^{2}$ \\ ${ }^{1}$ Ethiopian Institutes of Agricultural Research, Debre-Zeit Agricultural Research Centre, Department of Agricultural Economics Research, \\ Addis Ababa, Ethiopia \\ ${ }^{2}$ Ethiopian Institutes of Agricultural Research, Debre-Zeit Agricultural Research Centre, Department of Crop Science Research-Bread \\ Wheat-Project, Addis Ababa, Ethiopia
}

Email address:

aklil2002@gmail.com (A. Nigussie)

\section{To cite this article:}

Aklilu Nigussie, Wasihun Legesse. On-farm Validation of Bread Wheat Innovations for Supporting Extension Package Formulation in Ethiopia. Advances in Applied Sciences. Vol. 6, No. 2, 2021, pp. 27-33. doi: 10.11648/j.aas.20210602.14

Received: March 18, 2021; Accepted: May 11, 2021; Published: June 10, 2021

\begin{abstract}
Bread wheat is an important crop type in the Ethiopian production system because of its dual function both as a staple crop that improves food security and income-generating. This study had three intervention treatments on the production sector with the selected method of substantive cost-benefit analysis. The objectives of this research were; to conduct partial budget analysis of the treatments and to improve the recommendations by incorporating the benefits derived from the production process with economic constraints and opportunities for improving bread wheat production systems in Ethiopia at smallholder level. This study presents the partial budget analysis (PBA) framework for the economic analysis of different bread wheat package treatments for their benefit returns. The on-farm experiment was conducted in Hetosa and Tiyo district (Oromia regional state of Ethiopia) and Minjar Shenkora districts (Amhara regional state of Ethiopia) to assess the cost and the return of the treatments. The study investigated for costs and benefits associated with adaptation approaches employed by the farmers on farm packages expressing in monetary term and identify the most effective and economic options based on general information and responses on station and trials with the necessary agronomic practices. Findings from this study shows that the packages tested for the two sample districts varies accordingly; in Oromia regional, state the average grain yield for ATA, Extension and New research package was found 5070, 4830 and $4130 \mathrm{~kg}$ per hectare while for Amhara regional state 3870, 4330 and $5000 \mathrm{~kg}$ per hectare. The thousands of kernel weight was 36.2, 34.7 and 39.3 for Oromia while 34.6, 38.7 and 33.1 grams. The hectoliter weight was found 69.7, 69.9 and 70.3 in Oromia while it was 77.7, 79.3 and 79.2 in Amhara. The average benefit cost ratio was 1.41, 1.34 and 1.20 for Oromia whereas 1.83, 1.45 and 1.97 in Amhara. This states that the ATA package had a good return in Oromia while new research package had 1.97 returns for 1 Birr invested in bread wheat production in Amhara. The net revenue in Oromia samples per hectare had 16,615.20 (\$604.8), 16,602.67 (\$604.4), and 8,518.33 (\$310.1); whereas 15,413.73 (\$561.1), 24,027.20 (\$874.8), and 31,656.87 (\$1,152.4) Eth.Birr per hectare in Amhara regional state. With the exchange rate of $1 \mathrm{USD}=27.47$ Eth.Birr. In Amhara the new research package has a worth net return while in the Oromia ATA package had a worth net return as compared to other package treatments.
\end{abstract}

Keywords: Cost Benefit Analysis, Bread Wheat, Marginal Return, Yield, Kernel Weight, Hectoliter Weight

\section{Introduction}

An estimate by the UN-FAO indicates that, by 2050, the global demand for agricultural products will have risen by $50 \%$. Meeting this demand will require traditional development of improved cultivars coupled with modern best management practices as well as innovations that are transformational. Achievement of this goal on existing cropland will require a significant increase in rates of genetic gain in grain yield for crops such as wheat (Triticum aestivum L.), increasing the current rate of gain (ca. 1\% p.a.) by $30-40 \%[3,7]$.

Durum wheat (Triticum turgidum L. var durum Desf.) is the 10th most important and commonly cultivated cereal worldwide with a yearly production average of 40 million tones (MT) (2016/17). Typically, durum wheat production 
represents $5 \%$ of total wheat production with a planting area of $16 \mathrm{M}$ hectares globally (International Grains Council [5].

Wheat and wheat products could account for $20 \%$ of protein and calories consumption per capita for a global population of 9.7 billion in 2050 [6]. Durum is produced primarily for making pasta, but is also an important ingredient for couscous and bulgur, particularly in North Africa and the Middle East. These products use durum semolina resulting from milling of the hard-textured durum wheat kernel. In some countries such as Italy, regulatory standards specify that pasta must be made with $100 \%$ durum semolina [13].

East African countries cultivate almost 2 million ha of wheat, of which only 630,000 ha are farmed with durum wheat. Eritrea, Kenya, Somalia and Sudan combined harvested as little as 37,000 ha of durum wheat in 2014. Yet, these countries have maintained in their culinary taste the influence of the past Italian presence in the region, with pasta imports reaching 40 million USD in 2017 in Ethiopia only. In the case of Kenya, national production is sufficient to support the export of $€ 0.5$ million worth of pasta and durum grains [1].

Archaeological evidence suggests that naked emmer reached Ethiopia approximately 5000 years ago [11], probably arriving from the Levantine, through Egypt, along the Silk Road [9]. Today emmer wheat occupies approximately $7 \%$ of the wheat production in Ethiopia under the local name of Aja. Recent molecular data [8] indicated that Ethiopian farmers repeated what had been achieved already in West Asia before, by deriving durum wheat anew through the further domestication of emmer. This new origin of the same crop gave rise to a subspecies known as $\mathrm{T}$. turgidum ssp. aethiopicum or abyssinicum. Until relatively recently, landraces belonging to this subspecies were widely cultivated by smallholder farmers in Ethiopia, with up to $80 \%$ of the total durum land farmed with these unique biotypes [10].

With changes in the living standard of the rural population, no single household is able to produce everything it needs from its own farm. That is why marketing has become an important component of farm management. Farmers need to market their surplus produce and buy what they want and need for improving their lives. In doing so, they want to know which crop or package will bring the most profit or which will take less of their valuable resources, but still provide a good return [14].

Ethiopia is considered a center of diversity for durum wheat (Triticum turgidum var. durum). For millennia, using locally available germplasm and their traditional knowledge, farmers have been developing a broad range of genetically diverse durum wheat landraces adapted to the highly variable niche environments in the Ethiopian highlands, an area also referred to as the 'wheat belt' of the country. To date durum wheat cultivation is negligible and replaced by modern bread wheat varieties evolved from international and national breeding programs. This homogeneous genetic material, sometimes unable to fit the varied climatic conditions and tolerate ever-increasing biotic stresses, could expose farmers to risk in the event of climatic uncertainty and emergence of new strains of pathogens, with serious consequences on the stability of agricultural production [12].

The government of Ethiopia (GOE) has initiated the second Growth and Transformation Plan (GTP II) with renewed focus and vigor to bring structural transformation to the national economy. In this regard, the role of the national agricultural research system (NARS) in adapting, generating and delivering agricultural innovations and information is considered critical for success of the transformation agenda. Agricultural innovations have been the basis for the registered remarkable growth in the agricultural sector during GTP I [2].

In Ethiopia, the Ministry of Agriculture and Natural Resources (MoANR) with close support from NARS formulates agricultural extension packages based on a commodity approach. Under normal circumstances, extension packages are revisited annually in light of new innovations and recommendations generated by NARS. Nonetheless, it is increasingly recognized that the flow of new innovations from NARS alone may not be adequate to bring the desired rapid development and transformation of the agricultural sector, suggesting the need for making an inventory of a wide array of technologies and experiences elsewhere in the world. Advances in information communication technology (ICT) and the internet revolution, has made it easy to access and tap knowledge in the form of innovations from international research organizations and advanced agricultural universities in the developed world.

In an effort to boost smallholder access to up-to-date agricultural innovations, thereby, accelerate the transformation of smallholder agriculture, the Agricultural Transformation Agency of Ethiopia (ATA), has embarked on testing a number of crop innovations that have the potential to successfully enhance crop productivity. A recent assessment of the results of on-farm demonstrations of the ATA package, however, suggested the need for more information on the agronomic and economic merit of the package. Among these, the bread wheat recommendation package was one of that has been embarked to be tested by EIAR in collaboration with the Agricultural Transformation Agency (ATA) within station and on farm treatment.

Bread wheat is one of the major cereal crops grown in Ethiopia especially in the southeastern and central-mid and highland areas of the country. Wheat is the fourth important cereal crop with annual production of about 42.32 million quintals produced in an area of 1.664 million hectares in $2014 / 15$ cropping season with an average national yield of $25.43 \mathrm{q} / \mathrm{ha}$ and 4.02 percentage change of yield over the preceding year [2]. The higher wheat producing woredas are clustered in four main regional state locations. Though, the regional state location groups vary in size, the largest wheat producers are located in the Arsi-Bale area of Oromia regional state. Of the top 25 woredas, 19 are in Oromia, five in Amhara and one in Tigray. Overall, the highest wheat production woredas are principally located in three Oromia zones (West Arsi, Arsi, and Bale). This area, the "wheat belt" 
of Arsi-Bale zones, has nine of the top ten producing woredas as well as 16 of the top 25 woredas [14].

A number of factors influence what decisions smallholder farmers can make about their production process to apply different input packages for good net return. Household goals and objectives are in the forefront. A typical decision the farmer must make is whether to produce for home consumption or for the market, or both. Fluctuations and seasonal variability of input and output prices affect farm profitability with a different production package for bread wheat. It is therefore difficult for the farmer to predict, produce prices with application of packages. The uncertainty of weather always makes farming a business of risk especially in the smallholder. Therefore, the farmer must use inputs judicially, time farm activities properly and manage the farm returns. Most farmers have only a limited amount of such resources as capital, land, labor and technology. Whether these production factors are well used or not will likely determine farm profitability.

Costs of production analysis can benefit the producers indirectly through improved policy-making, better administrative decisions and more efficient markets. However, there is also potential for the data supplier, namely the farmers themselves, to reap direct benefits. At the farm level, Cost of production data contributes to improve the economic assessment of farm operation. They allow the producer to question his own operation and to benchmark it against the best practices of farms in the same region with similar characteristics. This, in turn, can lead to better informed decisions at the farm-level and improved market efficiency and performance.

Costs of production statistics provide farm extension workers with evidence to support their training and outreach activities, which helps evaluate an individual farm management practice against norms for the region. It also allows better targeting to the largest payoffs for their activities, which, in turn, elevates productivity.

Specific objectives were:

1) To compare biological superiority of the threetechnology package.

2) To conduct cost-benefit analysis of the innovative treatments as well as full technology package.

\section{Methodology}

Analyses of agronomic performances and cost of production involve observing and recording the wheat production processes starting from land preparation, planting, weeding, chemical applications, harvesting, etc. and transforming inputs into outputs considering the uses of physical, financial and human resources.

Testing locations: three testing locations were used to validate bread wheat package proposed by ATA. The on-farm testing locations were in the Arsi zone (Hetosa and Tiyo districts), Eastern Shewa zone (Minjar Shankora district) in addition to the two on-station testing locations in Kulumsa and Debre-Zeit agricultural research centers.

Parameters, data types and collection methods: Structured tables were used for the data collection. Data were collected on parameters that included the frequency of land preparation, time and method of sowing, seed covering, and harvesting. Agronomic parameters such as days to flowering, days to maturity, number of seeds per spike, number of tillers, TKW (thousand kernel weight), HLW (hectoliter weight), seed size, diseases and their scores, straw, yield, input and output prices were obtained.

Various input costs during the crop cycle, such as daily wages, grain price, cost of planting and threshing, labor costs (for human, animal and machine for various operations such as fertilizer and herbicide applications, hand weeding, and harvesting) were estimated and included in the analysis. However, the indirect cost or implicit cost such as the rental value and taxes on agricultural land was not included in the cost benefit analysis, and they were assumed fixed and did not vary with the level of output.

Data and Methods of Analysis

Relevant physical and cost data were collected from the experimental trial. Primary data on grain yield, straw, labor and oxen rent, and application rates of inputs such as seed, fertilizer and pesticides were based on recommendations used for the trial. Data were initially calculated for each farmer separately and then combined across two locations. All costs and revenues were quantified based on $500 \mathrm{~m}^{2}$ and converted to hectare base; furthermore, mean extrapolated to the hectare basis. Because of the wide variety of cost concepts, it is not possible to deal with all of them in a single section; for reason only the following items dealt with for short term benefit: -

Variable costs: Variable costs are a function of output and are only incurred if there is production. There is therefore a relationship between the volume of production and costs. For this study variable costs are seed, fertilizer, pesticide, wage rate, and oxen rent if production decisions have to be made of the quantities of variable inputs that must be used to maximize benefits over the short term, only variable costs are relevant since fixed costs remain constant.

Total costs: -Total costs are the sum of the total fixed and total variable costs, for this study of the short-term analysis variable only variable cost was taken.

Average costs: - Average or unit costs are the costs per unit such as cost per kilogram or quintal, per hectare, per liter. Average variable and average total costs can, depending on the circumstances, be calculated by dividing the specific cost amount of the corresponding units.

$$
A V C=\text { Tvc/yield of bread wheat }
$$

As in short run analysis, focus on the operational cost analysis and the fixed cost is constant then;

$$
A V C=V C \text { yield of bread wheat }
$$

The assumption is that for this research the fixed cost is constant and taken the variability among the costs that can be used for validation of benefits for different practices; so that ATC equals to AVC.

Marginal costs: - marginal costs are the extra or additional 
costs attached to the last unit of output. Marginal costs are calculated by dividing the change in costs $(\Delta$ costs $)$ by the change in output ( $\Delta$ yield), that is:

Marginal costs are only determined by an increase in variable costs. As long as marginal income is bigger than marginal costs, the benefit will be increased.

$$
\mathrm{MC}=\frac{\Delta \mathrm{TC}}{\Delta \mathrm{Q}}
$$

Tells us how much cost rises per unit increase in yield of bread wheat. The Marginal cost of any change in output is equal to the shape of the total cost curve along that interval of yield.

If the MC> AVC than the average cost is rising for a kilogram of bread wheat yield per plot or per hectare.

If the $\mathrm{MC}=\mathrm{AVC}$ than the average cost is at its lowest point and $\mathrm{MC}<\mathrm{AVC}$ than the average cost is falling for a kilogram of yield.

Gross margin:-

Benefit cost ratio: - is an indicator, used in costbenefit analysis, which attempts to summarize the overall value for money of a bread wheat production treatment. It is an important tool to assess the economics of farming. It is the ratio of all net value of bread wheat produced after deducting the costs of different inputs after their summation in the production process.

$$
\mathrm{BCR}=\frac{G B-T V C}{T V C}
$$

Where: -

$\mathrm{BCR}=$ benefit cost ratio

$\mathrm{GB}=$ gross benefits

$\mathrm{TVC}=$ total variable cost

The marginal rate of return: - technically, the marginal rate of return is the marginal return or the amount of revenue per additional item, divided by marginal cost (the cost per additional item produced). In other words, it's the amount of additional revenue that a bread wheat production can expect to earn per each additional Birr that it spends on producing. Using the marginal rate of return, a farmer can determine whether or not its operations have a benefit or loss.

The marginal rate of return becomes most powerful when it's used as a decision-making tool. As long as a marginal rate of return is greater than one, a farmer can make a profit by producing one additional unit. Because the marginal rate of return tends to decrease as more and more units are produced, a farmer will maximize its benefits by expanding production until its marginal rate is one. Basically, this is where marginal revenue equals marginal cost $(\mathrm{MR}=\mathrm{MC})$. If a firm produces beyond this point, the marginal rate of return drops below one $(\mathrm{MR}<1)$, and the firm will be spending more per each additional item than it is bringing in revenue.

\begin{tabular}{|c|c|c|c|c|}
\hline Location & Data recorded & ATA package & Extension package & Research package \\
\hline \multirow{6}{*}{ Farm I } & Yield (Qt/ha) & 45.2 & 47.2 & 39.6 \\
\hline & TKW (gm) & 37.4 & 35.5 & 38.0 \\
\hline & HLW (g/hl) & 69.5 & 69.0 & 70.5 \\
\hline & No seed/spike & 72.0 & 68.0 & 72.0 \\
\hline & Number of tiller & 10.0 & 9.0 & 11.0 \\
\hline & Straw (Qt/ha) & 10.5 & 12.5 & 11.5 \\
\hline \multirow{6}{*}{ Farm II } & Yield (Qt/ha) & 48.4 & 39.0 & 33.2 \\
\hline & TKW (gm) & 37.8 & 35.1 & 39.5 \\
\hline & HLW (g/hl) & 68.4 & 69.5 & 70.0 \\
\hline & No seed/spike & 70.0 & 72.0 & 69.0 \\
\hline & Number of tiller & 11.0 & 10.0 & 10.0 \\
\hline & Straw (Qt/ha) & 18.7 & 16.4 & 15.4 \\
\hline \multirow{6}{*}{ On station } & Yield (Qt/ha) & 58.6 & 58.6 & 51.0 \\
\hline & TKW (gm) & 33.4 & 33.4 & 40.3 \\
\hline & HLW (g/hl) & 71.1 & 71.1 & 70.2 \\
\hline & No seed/spike & 74.0 & 74.0 & 73.0 \\
\hline & Number of tiller & 12.0 & 11.0 & 9.0 \\
\hline & Straw (Qt/ha) & 15.0 & 14.0 & 13.0 \\
\hline \multirow{6}{*}{ Average } & Yield (Qt/ha) & 50.7 & 48.3 & 41.3 \\
\hline & TKW (gm) & 36.2 & 34.7 & 39.3 \\
\hline & HLW (g/hl) & 69.7 & 69.9 & 70.3 \\
\hline & No seed/spike & 72.0 & 71.0 & 71.0 \\
\hline & Number of tiller & 11.0 & 10.0 & 10.0 \\
\hline & Straw (Qt/ha) & 14.7 & 14.3 & 13.3 \\
\hline
\end{tabular}

Table 1. Bread wheat yield performance in response to different levels of nitrogen fertilizer.

Source: own data, compute 2018

N.B.: Sample of Hetosa and Tiyo district and Kulmsa Agricultural Center (on station)

YLD $=$ Yield

$\mathrm{TKW}=$ thousand kernel weight

HLW= hectoliter weight

$\mathrm{Qt}=\mathrm{a}$ quintal $=100 \mathrm{~kg}$

ha $=$ hectare 


\section{Results and Discussions}

\section{Agronomic Performance}

In mean grain yield for studies conducted at the Kulumsa research center on station and on two farmers land, ATA package is higher than package and research. HLW and TKW of Research plots are slightly higher than Extension package and ATA package. The Mean values of number of tillers and number of seeds per spike of ATA package are slightly higher than Extension package and research. The number of tillers is higher in ATA package which results in higher in grain yield compared to other two. The mean number of seeds per spike (72 seeds) is slightly higher in ATA package, whereas equal in package and research (71 seeds). The mean amount of straw for KARC (three location: on station, on farm I and on farm II) also higher in ATA package than extension Package and Research package (Table 1). Research plots yield of bread wheat in the farm I and II was much higher than ATA package and Extension package plots yield. The average yield performance of research plot is better than ATA and Extension package plots.

Table 2. Bread wheat yield performance in response to different levels of nitrogen fertilizer.

\begin{tabular}{|c|c|c|c|c|}
\hline Location & Data Recorded & ATA package & Extension package & Research package \\
\hline \multirow[t]{3}{*}{ Farm I } & Yield (Qt/ha) & 45.6 & 57.0 & 68.4 \\
\hline & TKW (gm) & 35.6 & 38.1 & 37.3 \\
\hline & HLW (g/hl) & 77.2 & 78.0 & 77.6 \\
\hline \multirow[t]{4}{*}{ Farm II } & Yield (Qt/ha) & 50.0 & 42.0 & 49.0 \\
\hline & TKW (gm) & 38.9 & 41.1 & 26.5 \\
\hline & HLW (g/hl) & 79.8 & 79.2 & 79.2 \\
\hline & Yield (Qt/ha) & 20.5 & 31.0 & 32.6 \\
\hline \multirow{2}{*}{ On station } & HLW (g/hl) & 76.0 & 80.8 & 80.8 \\
\hline & Yield (Qt/ha) & 38.7 & 43.3 & 50.0 \\
\hline \multirow[t]{2}{*}{ Average } & TKW (gm) & 34.6 & 38.7 & 33.1 \\
\hline & HLW (g/hl) & 77.7 & 79.3 & 79.2 \\
\hline
\end{tabular}

Source: own data compute 2018

N.B.: Sample of Minjar Shenkora district and Debre-Zeit Agricultural Center (on station)

YLD = Yield;

TKW= thousand kernel weight;

HLW $=$ hectoliter weight

$\mathrm{Qt}=\mathrm{a}$ quintal $=100 \mathrm{~kg}$

ha $=$ hectare

The location of the Minjar Shenkora district the yield varies from the farm to farm because of different heterogeneous factors that are controlled in the treatment like soil type, soil fertility and other environmental factors. From the farm I and II had a different yield with the same treatments applied; ATA package in the first farm yield in quintal per ha was 45.6 while it was 50 in the second. Considering new research package in the two farms was found a yield of 68.4 and 49 quintal per hectare. The maximum total average yield was found in the new research package which was 50 quintal per hectare as compared to 43.3 and 38.7 quintals for extension and ATA package respectively (Table 2 ).

The highest mean grain yield $(45.8 \mathrm{Qt} / \mathrm{ha})$ performance for all locations exhibited by package followed by Research (45.14 Qt/ha) whereas ATA package stands in third place with mean values of $44.72 \mathrm{Qt} / \mathrm{ha}$.

Table 3. Bread wheat performance in response to different levels of nitrogen fertilizer.

\begin{tabular}{|c|c|c|c|c|c|c|c|c|c|}
\hline \multirow[b]{2}{*}{ Sample district } & \multicolumn{3}{|c|}{ Mean YLD } & \multicolumn{3}{|c|}{ Mean TKW } & \multicolumn{3}{|c|}{ Mean HLW } \\
\hline & $\begin{array}{l}\text { ATA } \\
\text { package }\end{array}$ & $\begin{array}{l}\text { Extension } \\
\text { package }\end{array}$ & $\begin{array}{l}\text { Research } \\
\text { package }\end{array}$ & $\begin{array}{l}\text { ATA } \\
\text { package }\end{array}$ & $\begin{array}{l}\text { Extension } \\
\text { package }\end{array}$ & $\begin{array}{l}\text { Research } \\
\text { package }\end{array}$ & $\begin{array}{l}\text { ATA } \\
\text { package }\end{array}$ & $\begin{array}{l}\text { Extension } \\
\text { package }\end{array}$ & $\begin{array}{l}\text { Research } \\
\text { package }\end{array}$ \\
\hline Hetosa and Tiyo & 50.74 & 48.26 & 40.28 & 36.19 & 34.65 & 39.25 & 69.68 & 69.85 & 70.25 \\
\hline Minjar Shenkora & 38.70 & 43.33 & 50.00 & 34.62 & 38.66 & 33.10 & 77.66 & 79.30 & 79.20 \\
\hline Average & 44.72 & 45.80 & 45.14 & 35.41 & 37.66 & 36.18 & 73.67 & 74.58 & 74.73 \\
\hline
\end{tabular}

Source: own data, compute 2018

NB: YLD = Yield;

$\mathrm{TKW}=$ thousand kernel weight;

$\mathrm{HLW}=$ hectoliter weight

\section{Cost- benefit Analysis}

The Marginal Principle: is the concept used to explain the influence of a change. It is especially used by economists because they are very interested in the influence of any change. Marginal, however; also important for farmers when they have to decide what package to use, how and how much they should produce applying the specific package. Marginal basically means the influence or effect that a change in the input will have on the output. That is, what "extra" or "additional" yield or loss will result from a change in of inputs? A practical example of marginal is what difference there is in bread wheat yields if 150 or $200 \mathrm{~kg}$ fertilizer is 
applied while all other inputs are kept constant. It therefore concerns the additional maize crop that is harvested with the extra $50 \mathrm{~kg}$ fertilizer; this is briefly called the marginal bread wheat yield. This change in output or input is denoted by the Greek letter delta $(\Delta)$.

Calculating benefits require the yield of wheat obtained and the farm gate prices that farmers receive from selling of wheat. Table 4 gives per plot $\left(500 \mathrm{~m}^{2}\right)$ wheat yield, input costs and revenues obtained in the two testing locations of extension package and ATA package. Average grain yield was relatively high for the ATA package in Arsi (Hetosa and Tiyo district) with a yield of about $258 \mathrm{~kg} /$ plot or about 52 quintals per hectare. The lowest average yield was observed for the ATA package in East Shewa in Minjar-Shenkora district (192.5 kilogram per $500 \mathrm{~m}^{2}$ land area). Relatively, the highest yield was also observed for the current research input package in the same area with a yield level of 250 kilograms per the same plot area at Minjar-Shenkora. Comparing per plot net revenues, there was no net revenue difference between extension and ATA packages in Hetosa and Tiyo districts of Arsi zone. However, in Minjar-shenkora districts, the net revenue from the ATA package was the lowest compared to the net revenues of all locations and as well as all extensions and ATA packages (Table 4).

Table 4. Per plot cost- benefit analysis for bread wheat.

\begin{tabular}{|c|c|c|c|c|c|c|}
\hline \multirow[b]{2}{*}{ Inputs (costs)/yield (Revenue) } & \multicolumn{3}{|c|}{ Arsi (Hetosa and Tiyo district) } & \multicolumn{3}{|c|}{ Minjar Shenkora District } \\
\hline & $\begin{array}{l}\text { Extension } \\
\text { Package } \\
\end{array}$ & ATA Package & $\begin{array}{l}\text { Research } \\
\text { Package }\end{array}$ & $\begin{array}{l}\text { Extension } \\
\text { Package }\end{array}$ & ATA Package & $\begin{array}{l}\text { Research } \\
\text { Package }\end{array}$ \\
\hline Seed (Birr/plot) & 50.00 & 50.00 & 50.00 & 60.00 & 60.00 & 60.00 \\
\hline Fertilizer (Birr/plot) & 124.00 & 260.25 & 168.15 & 99.02 & 209.69 & 143.28 \\
\hline Pesticides (Birr/plot) & 0.00 & 10.45 & 0.00 & 0.00 & 0.00 & 0.00 \\
\hline Labor costs (Birr/plot) & $1,591.67$ & $1,833.33$ & $1,683.33$ & $1,151.67$ & $1,271.67$ & $1,271.67$ \\
\hline Total input costs (Birr/plot) & $2,028.87$ & $2,441.91$ & $2,166.42$ & $1,446.14$ & $1,696.81$ & $1,630.41$ \\
\hline Yield (kg/plot) & 229.00 & 257.57 & 206.33 & 216.67 & 192.50 & 250.00 \\
\hline Grain value (Birr/plot) & $2,290.00$ & $2,575.67$ & $2,063.33$ & $2,647.50$ & $2,347.50$ & $3,057.00$ \\
\hline Straw value (Birr/plot) & 569.00 & 697.00 & 529.00 & 128.75 & 120.00 & 156.25 \\
\hline Total Revenue (Birr/plot) & $2,859.00$ & $3,272.67$ & $2,592.33$ & $2,647.50$ & $2,467.50$ & $3,213.25$ \\
\hline Net revenue (Birr/plot) & 830.13 & 830.76 & 425.92 & $1,330.11$ & 770.69 & $1,582.84$ \\
\hline Net revenue (Birr/hectare) & $16,602.67$ & $16,615.20$ & $8,518.33$ & $26,602.20$ & $15,413.73$ & $31,656.87$ \\
\hline
\end{tabular}

Source: own data, compute 2018

N.B.: Plot area is $500 \mathrm{~m}^{2}$

Per hectare average costs, revenues and net revenues were calculated using input and output prices as shown in Table 5. The average net revenue per hectare was about 16,603 Birr and 16,615 Birr for extension and ATA packages in Arsi (Hetosa and Tiyo district), respectively, implying that there was almost no net revenue difference between extension and
ATA packages in this area. However, the net revenue showed much difference in Minjar-shenkora between the extension and innovation packages yielding net revenue of 24,027 Birr/ha for extension package and 15,414 Birr/ha for the ATA package.

Table 5. Per hectare net returns, cost of production and benefit-cost ratio.

\begin{tabular}{|c|c|c|c|c|c|c|}
\hline \multirow[b]{2}{*}{ Inputs (costs)/yield (Revenue) } & \multicolumn{3}{|c|}{ Arsi (Hetosa and Tiyo district) } & \multicolumn{3}{|c|}{ Minjar Shenkora District } \\
\hline & $\begin{array}{l}\text { Extension } \\
\text { Package }\end{array}$ & $\begin{array}{l}\text { ATA } \\
\text { Package }\end{array}$ & $\begin{array}{l}\text { Research } \\
\text { Package }\end{array}$ & $\begin{array}{l}\text { Extension } \\
\text { Package }\end{array}$ & $\begin{array}{l}\text { ATA } \\
\text { Package }\end{array}$ & $\begin{array}{l}\text { Research } \\
\text { Package }\end{array}$ \\
\hline Total input costs (Birr/plot) & $2,028.87$ & $2,441.91$ & $2,166.42$ & $1,446.14$ & $1,696.81$ & $1,630.41$ \\
\hline Total input costs (Birr/hectare) & $40,577.33$ & $48,838.13$ & $43,328.33$ & $28,922.80$ & $33,936.27$ & $32,608.13$ \\
\hline Yield (kg/plot) & 229.00 & 257.57 & 206.33 & 216.67 & 192.50 & 250.00 \\
\hline Yield (Qt/hectare) & 45.80 & 51.51 & 41.27 & 43.33 & 38.50 & 50.00 \\
\hline Total Revenue (Birr/plot) & $2,859.00$ & $3,272.67$ & $2,592.33$ & $2,647.50$ & $2,467.50$ & $3,213.25$ \\
\hline Net revenue (Birr/hectare) & $16,602.67$ & $16,615.20$ & $8,518.33$ & $24,027.20$ & $15,413.73$ & $31,656.87$ \\
\hline Cost of production (Birr/Qt) & 885.97 & 948.13 & $1,049.87$ & 667.50 & 881.46 & 652.16 \\
\hline Benefit-cost ratio & 1.41 & 1.34 & 1.20 & 1.83 & 1.45 & 1.97 \\
\hline
\end{tabular}

Source: own data, compute 2018

N.B.: $\mathrm{Qt}=$ a quintal $=100 \mathrm{~kg}$

The present cost-benefit analysis used costs and benefits using different amounts of farm inputs in wheat production in selected study districts and thereby compared and saw the differences between the location and the packages in costs and benefits as indicated in the above table. Though there were minor differences in input and output prices, there were major differences in average net revenues between locations and among the treatments (extension, ATA and research package). Relatively, the least average cost per hectare was observed for the extension package and the highest cost per 
hectare was seen for the innovation package in Hetosa and Tiyo district. Likewise, average cost per hectare was higher for in an ATA package in Minjar-shenkora when compared to the costs of extension and research packages.

Overall, the difference in the average net benefit was negligible between extension and ATA packages in Arsi's (Hetosa and Tiyo district) with benefit-cost ratio of 1.41 and 1.34 for extension and ATA packages respectively. The benefit cost ratio for extension and ATA packages were 1.83 and 1.45 respectively in the Minjar-shenkora district. The cost of production or breakeven price was also the highest (948.13 Birr/ql) for ATA package in Hetosa and Tiyo district when compared to the breakeven price of extension packages. Similarly, in the Minja-shenkora district, the breakeven price was the highest for an ATA package (881.46 Birr/al) when compared to extension and research packages. It has to be noted that the average cost per average yield gives a breakeven price. Breakeven price and yield are the values that cover the costs of production of farmer. The breakeven price gives the values at which the farmers have no gain or loss. It's the price or yield above the breakeven point that make farmers profitable.

\section{Conclusion and Recommendation}

This study was carried out in Arsi (Hetosa and Tiyo district) and East Shewa (Minjar-shenkora) areas to analyze the costs and benefits of producing bread wheat using the current agricultural extension and ATA packages. The costs of production and net benefits were analyzed and determined for producing bread wheat at six locations (four on farmers' fields and two on research station fields). The testing locations were in Arsi zone (three locations) and in East shewa (three locations) zone. Input, output and price data were collected from the six locations using technical assistants from Kulumsa and Debre-Ziet agricultural research centers. It was found out that bread wheat net benefit had no difference between extension and ATA packages in Arsi (Hetosa and Tiyo) whereas the net benefit showed much difference between extension and innovation packages, with the innovation package relatively depicting minimum net benefit per plot or per hectare. However, the costs of production and the net benefits calculated based on one year input and output data and price as well as small plot size and few locations may not necessarily hold true for other many locations and years. So, it is suggested that the average costs of production and net benefit calculations need to be based on several locations' and several years' input, output and price data.

\section{References}

[1] Amadou Tidiane Sall et al, 2019. Durum Wheat (Triticum durum Desf.): Origin, Cultivation and Potential Expansion in Sub-Saharan Africa; www.mdpi.com/journal/agronomy Institut Sénégalais de Recherches Agricoles (ISRA), Saint-Louis 46024, Senegal.
[2] CSA (Central Statistical Agency of Ethiopia), 2015. Area and production of major crops, agricultural sample survey vol. 1, May 2015, Addis Ababa.

[3] Cassman, K. G., and Grassini, P. (2020). A global perspective on sustainable intensification research. Nat. Sustain. 3, 262268. doi: 10.1038/s41893-020-0507-8.

[4] CRP-WHEAT (2016). Wheat Agri-Food Systems Proposal 2017-2022”. Research Program on Wheat, (CGIAR). https://cgspace.cgiar.org/handle/10947/4421?show=full

[5] FAO (2017). The Future of Food and Agriculture - Trends and Challenges. Rome: Food and Agriculture of the United Nations.

[6] Diego NAZIRI et al., 2008. Durum wheat production in South-Eastern Ethiopian highlands: status, constraints and prospects:

https://www.researchgate.net/publication/267095321_Durum wheat_production_in_South [accessed Jun 07 2021].

[7] International Grains Council [IGC] (2020). World Grain Statistics 2016. https://www.igc.int/en/subscriptions/subscription.aspx (accessed June 07, 2021).

[8] Kabbaj, H.; Sall, A. T.; Al-Abdallat, A.; Geleta, M.; Amri, A.; Filali-Maltouf, A.; Belkadi, B.; Ortiz, R.; Bassi, F. M. Genetic Diversity within a Global Panel of Durum Wheat (Triticum durum) Landraces and Modern Germplasm Reveals the History of Alleles Exchange. Front. Plant Sci. 2017, 8, 1277. [CrossRef] [PubMed].

[9] Luo, M. C.; Yang, Z. L.; You, F. M. The structure of wild and domesticated emmer wheat populations, gene flow between them and the site of emmer domestication. Theor Appl. Genet. 2007, 114, 947-959. [Cross Ref].

[10] Mengistu, D. K.; Kirosa, Y. A. Y.; Pè, M. E. Phenotypic diversity in Ethiopian durum wheat (Triticum turgidum var. durum) landraces. Crop J. 2015, 3, 190-199. [Cross Ref].

[11] National Research Council. Lost Crops of Africa: Volume I: Grains; the National Academies Press: Washington, DC, USA, 1996.

[12] The Federal Democratic Republic of Ethiopia; Growth and Transformation Plan (GTP) 2010/11-2014/15; Draft; Ministry of Finance and Economic Development (MoFED); September 2010 Addis Ababa.

[13] Sopiwnyk, E. (2018). "Durum production and consumption, a global perspective," in Sustainable Production of Durum Wheat in Canada, (Bannockburn, IL: Barilla America Inc), 59.

[14] Takele Zegeye et al., 2000. Estimating costs and benefits on crop production; A Simplified Guide for Smallholder Farmers in Ethiopia: Regional Land Management Unit (RELMA), Swedish International Development Cooperation Agency, Sida.

[15] Warner, J., Stehulak T. and Kasa L. 2015. Woreda-Level Crop Production Rankings in Ethiopia: Agricultural Transformation Agency (ATA) and International Food Policy Research Institute (IFPRI), Addis Ababa, Ethiopia. 